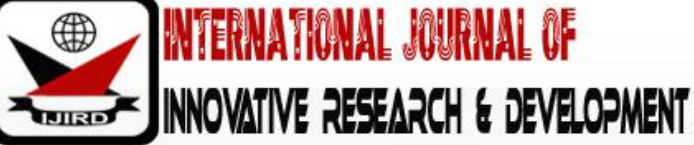

ISSN 2278 - 0211 (Online)

\section{Strategy Formulating Using IFE, EFE, SWOT and QSPM Matrix Case study: PT Total Bangun PersadaTbk}

\begin{tabular}{|c|}
\hline Rintani Dyan Pangastuti \\
Student, Master of Management Universitas Pelita Harapan Surabaya, Indonesia \\
Bryan Utama Angka \\
Student, Master of Management Universitas Pelita Harapan Surabaya, Indonesia \\
Mohit Amardas Lakhwani \\
Student, Master of Management Universitas Pelita Harapan Surabaya, Indonesia \\
Jitro Behuku \\
Student, Master of Management Universitas Pelita Harapan Surabaya, Indonesia \\
James Leonardo Putra \\
Student, Master of Management Universitas Pelita Harapan Surabaya, Indonesia
\end{tabular}

\begin{abstract}
:
This study present analyzing the strengths, weaknesses, opportunities, threats of PT. Total Bangun Persada Tbk that used to find new strategic for this company. From the SWOT analysis, this study determines the strategic to increasing competitiveness for PT. Total Bangun Persada Tbk. To formulating the competitiveness strategic, this study using IE, EFE matrix and QSPM matrix. The research based on secondary data from 2017 annual report of this company.
\end{abstract}

Keywords: SWOT Analysis, IE, EFE, QSPM

\section{Introduction}

Today, the construction business in Indonesia is very developed. The large amount of infrastructure development has made the growth of construction services grow. PT. Total Bangun Persada Tbk is one of the largest construction companies in Indonesia serving various fields. As a large construction company, PT. Total Bangun Persada Tbk must remain vigilant and continue to innovate in the face of the development and growth of construction companies in Indonesia. The increasing number of construction companies in Indonesia makes the level of competition increase and demand PT. Total Bangun Persada Tbk to think about and formulate new strategies that can be applied to maintain its position as a large construction company in Indonesia.

The purpose of this study is to determine the strategies that can be used by PT. Total Bangun Persada Tbk to be able to continue to improve strong competitiveness by analyzing the strengths, weaknesses, opportunities, and threats that are owned by PT. Total Bangun Persada Tbk.

Internal factors are factors that can affect the performance of a company that comes from within the company itself, or in other words can be controlled by the company concerned. In the process of formulating a strategy a company needs to identify and evaluate the internal environment of the company. The results of the identification and evaluation are expected by the company to know the profile of the company's strategic advantage. So that the company can anticipate business opportunities and respond to existing business threats quickly.

External factors are factors that influence the performance of the company and come from outside the company. External factors are very important to analyze because they can provide an overview of the opportunities and threats that are being faced by the company.

SWOT is an analysis carried out by looking at four perspectives, namely strength used to analyze the strengths of a company, weakness is used to analyze the limitations experienced by companies, opportunity to analyze environmental situations that benefit companies and threat to analyze situations that do not profitable and can threaten a company (Suci, 2015). The objective in determining the strategy used from the SWOT results is basically to produce a viable alternative strategy, not to determine the best strategy, so that a manager can judge that not all strategies in SWOT are chosen to be developed.

Quantitative Strategic Planning Matrix (QSPM) is a high-level strategic management approach for evaluating possible strategies. Quantitative Strategic Planning Matrix or a QSPM provides an analytical method for comparing feasible alternative actions. The QSPM method falls within so-called stage 3 of the strategy formulation analytical framework. According to (Zulkarnaen dan Sutopo, 2013) in (Suci, 2015) QSPM is a tool used to determine the best strategy that must be done by the company to achieve optimal results. Based on research of (Zulkarnaen dan Sutopo, 2013) in (Hany S, 
Mas'ud E, Imam S, 2016), the advantage of using QSPM matrix is that there is no limit in evaluating the strategies used by the company.

\section{Methodology}

This study was practical-applied study that is done by SWOT matrix method and formulated strategy of a company using IE, EFE matrix, and QSPM matrix. For information analysis of internal and external environment, this study based on secondary data that uses data from 2017 annual report of this company.

\subsection{Matrix Analysis}

From the annual report in 2017, it can be concluded that there are several internal factors that affect the performance of PT. Total Bangun Persada Tbk, these factors include:

\subsubsection{Management}

- Having a CSR Program - In accordance with government regulations, every company must have a CSR program

- Do not have an adequate HR consultant bureau

- Concentrate on HR - Hold training etc.

- Applying Lean Construction

\subsubsection{Research and Development}

- Innovation

\subsubsection{Marketing}

- Clear segmentation

- Put the client as the main one

- There are no ads specific to the company

- Not all big cities are affordable

\subsubsection{Production / Operation}

- Modern Technological

\subsubsection{External Factor Analysis}

\subsubsection{Economy}

- There is an increase in material prices, fuel, even the rupiah exchange rate

- Construction companies are basic needs

- MEA Opening

\subsubsection{Social / Demographic / Environment}

- The amount of national infrastructure development

- Increased demand for office space and high occupancy in major cities in Indonesia

\subsubsection{Competitive}

- The emergence of new construction companies and old construction companies

- There is a price war strategy

\subsubsection{Technology}

- There is a high complexity in carrying out work

- The possibility of land sliding around the project

\subsection{Internal Factor Evaluation (IFE) Matrix}

From the internal and external factor analysis above, we will input the result of IFE analysis was obtained through a number of indicators of Strength and Weakness. The ratings range from 4 to 1, where 4 means a superior response, 3 above average response, 2 - average response and 1 - poor response. 


\begin{tabular}{|c|c|c|c|}
\hline Key Factor & Weight & Rating & Weighted Score \\
\hline $\begin{array}{c}\text { Having a CSR Program - In accordance with government regulations, } \\
\text { every company must have a CSR program }\end{array}$ & 0.08 & 3 & 0.24 \\
\hline Do not have an adequate HR consultant bureau & 0.05 & 1 & 0.05 \\
\hline Concentrate on HR - Hold training etc. & 0.10 & 4 & 0.40 \\
\hline Applying Lean Construction & 0.10 & 3 & 0.30 \\
\hline Have innovation & 0.12 & 4 & 0.48 \\
\hline Have clear segmentation & 0.15 & 4 & 0.60 \\
\hline Put the client as the main one & 0.15 & 4 & 0.60 \\
\hline There are no ads specific to the company & 0.05 & 2 & 0.10 \\
\hline Not all big cities are affordable & 0.10 & 2 & 0.20 \\
\hline Using modern technology & 0.10 & 3 & 0.30 \\
\hline Total & 1.00 & & 3.27 \\
\hline
\end{tabular}

Table 1: Internal Factor Evaluation (Ife) Matrix

\subsection{External Factor Evaluation (EFE) Matrix}

From the internal and external factor analysis above, we will input the result of EFE analysis was obtained through a number of indicators of Opportunities and Threat. The ratings range from 4 to 1 , where 4 means a superior response, 3 - above average response, 2 - average response and 1 - poor response.

\begin{tabular}{|c|c|c|c|}
\hline External Factor Analysis & Weight & Rating & Weighted Score \\
\hline $\begin{array}{l}\text { There is an increase in material prices, fuel, even the rupiah exchange } \\
\text { rate }\end{array}$ & 0.15 & 4 & 0.60 \\
\hline Construction companies are basic needs & 0.15 & 4 & 0.60 \\
\hline Opening of MEA & 0.05 & 3 & 0.15 \\
\hline The amount of national infrastructure development & 0.15 & 3 & 0.45 \\
\hline $\begin{array}{l}\text { Increased demand for office space and high occupancy in major cities } \\
\text { in Indonesia }\end{array}$ & 0.15 & 4 & 0.60 \\
\hline $\begin{array}{l}\text { The emergence of new construction companies and old construction } \\
\text { companies }\end{array}$ & 0.20 & 4 & 0.80 \\
\hline There is a price war strategy & 0.05 & 4 & 0.20 \\
\hline
\end{tabular}

Table 2: External Factor Evaluation (EFE) Matrix

From the calculation of the analysis of internal and external factors, it can be seen that the value of the analysis of internal factors of PT. Total Bangun Persada Tbk is 3.27 and the value of the analysis of external factors is 3.75. From these calculations, it is known that PT. Total Bangun Persada Tbk is a company that grows and builds. Based on this, the strategy that can be done is to use market penetration, market development, product development.

Market penetration strategies can be carried out by maintaining or even increasing market share through competitive pricing, willing to take on new projects that may not be too large in contract value, or can be done by commercial advertisements that have not been done so far. In addition, to penetrate the market, PT. Total Bangun Persada Tbk can also use consumer loyalty programs, for example by giving rewards to consumers who have high contract value.

In developing the market, PT. Total Bangun Persada Tbk should offer construction services in new markets, this can be achieved by adjusting the geographical conditions in the market. This adjustment can also be done by making calculations or providing different price and quality standards in each new market area so that it can attract new consumers to PT. Total Bangun Persada Tbk.

In product development, PT. Total Bangun Persada Tbk can begin to open a wider range of construction services, not limited to high rise buildings, but can also expand in services by building social buildings, such as hospitals, mosques, churches, or other social buildings.

\subsection{SWOT Analysis}

From analysis of internal and external factors, SWOT analysis can be made. SWOT analysis is used to find strategic choices that can be used and applied at PT. Total Bangun Persada by combining strengths, weaknesses, opportunities, and threats that exist in the company. Swot analysis is shown in the following table: 


\begin{tabular}{|c|c|c|}
\hline & Strength & Weakness \\
\hline SWOT & $\begin{array}{l}\text { 1. Having Innovation } \\
2 . \quad \text { Having a CSR Program } \\
\text { 3. Having Clear } \\
\text { Segmentation } \\
\text { 4. Having HR Development } \\
\text { Priorities } \\
\text { 5. Using } \\
\text { technology } \\
\text { 6. Placing the client as the } \\
\text { main one }\end{array}$ & $\begin{array}{l}\text { 1. Don't have an adequate } \\
\text { HR consultant bureau } \\
2 \text { There are no } \\
\text { advertisements for the } \\
\text { company } \\
\text { 3. Not all big cities are } \\
\text { affordable }\end{array}$ \\
\hline Opportunity & $\mathrm{SO}$ & WO \\
\hline $\begin{array}{l}\text { 1. The amount of national } \\
\text { infrastructure development } \\
2 \text {. Increased demand for office } \\
\text { and residential areas in major cities in } \\
\text { Indonesia } \\
\text { 3. Construction companies are } \\
\text { basic needs } \\
4 \text { Opening of MEA }\end{array}$ & $\begin{array}{l}\text { 1. Continues to develop } \\
\text { innovations (S1, O1, O2) } \\
\text { 2. Opening } \\
\text { opportunities for foreign workers } \\
\text { (MEA) to join (S4, S5, O4) } \\
\text { 3. Widen the range of } \\
\text { service areas - Product } \\
\text { Diversification (S3, O3, S6) }\end{array}$ & $\begin{array}{l}\text { 1. Make a consultant } \\
\text { bureau for promotion (W1, O4) } \\
2 . \quad \text { Establish branch offices } \\
\text { in major cities in Indonesia (O3, } \\
\text { O2, W3) }\end{array}$ \\
\hline Threat & ST & WT \\
\hline $\begin{array}{l}1 . \text { The emergence of new } \\
\text { construction companies and old } \\
\text { construction companies } \\
\text { 2. There is an increase in } \\
\text { material prices, fuel, even the rupiah } \\
\text { exchange rate } \\
3 \text {. The existence of a high } \\
\text { complexity in the implementation of } \\
\text { the work } \\
4 \text { Possibility of land sliding } \\
\text { around the project } \\
5 \text { There is a price war strateov }\end{array}$ & $\begin{array}{l}\text { 1. Strengthening corporate } \\
\text { image through CSR activities (S6, } \\
\text { S2,T1) } \\
\text { 2. Still prioritizing quality } \\
\text { even though the price is attacked } \\
(\mathrm{T} 2, \mathrm{~T} 1, \mathrm{~T} 5, \mathrm{~S} 6)\end{array}$ & $\begin{array}{l}\text { 1. Building cooperation } \\
\text { with local contractors in other } \\
\text { major cities }(\mathrm{W} 3, \mathrm{~T} 1)\end{array}$ \\
\hline
\end{tabular}

Table 3: SWOT Analysis

Through combining strengths, weaknesses, opportunities and threats, several strategies can be formulated to be applied at PT. Total Bangun Persada Tbk to improve competitiveness. Some of the strategies formulated are continuing to develop innovations, widen the range of service areas - diversification, making a consultant for promotion, establishing a branch office in major cities in Indonesia, strengthening corporate image through CSR activities, still prioritizing quality events though the price attack, and building cooperation with local contractors in other major cities.

For continuing to develop innovations the company is expected to continue to develop innovation. It can be done by making new building designs more attractive, using materials that are more environmentally friendly, or other things in accordance with the demands of today's development. For Widen the range of services areas, companies can provide other service options, namely by venturing into the construction of social buildings such as places of worship, schools or hospitals. For establishing a branch office in major cities in Indonesia, companies can collaborate with local contracting companies in each city.

\subsection{Quantitative Strategic Planning Matrix (QSPM)}

From each existing strategy from SWOT analysis, the three best strategies were chosen to be analyzed using the QSPM matrix which can then be developed and applied as a company strategy to increase the competitive advantage of the company. QSPM matrix analysis can be seen in the table below: 


\begin{tabular}{|c|c|c|c|c|c|c|c|c|}
\hline \multirow{2}{*}{ No } & \multirow{2}{*}{$\begin{array}{l}\text { Indicator } \\
\text { Strength }\end{array}$} & \multirow{2}{*}{ Weight } & \multicolumn{2}{|c|}{$\begin{array}{c}\text { Innovation } \\
\text { Development }\end{array}$} & \multicolumn{2}{|c|}{ Business Expansion } & \multicolumn{2}{|c|}{ HR Development } \\
\hline & & & Rating & $\begin{array}{c}\text { Weighted } \\
\text { Score }\end{array}$ & Rating & $\begin{array}{c}\text { Weighted } \\
\text { Score }\end{array}$ & Rating & $\begin{array}{l}\text { Weighted } \\
\text { Score }\end{array}$ \\
\hline 1 & Innovation & 0.15 & 4 & 0.60 & & & 3 & 0.45 \\
\hline 2 & CSR Program & 0.05 & & & & & 2 & 0.10 \\
\hline 3 & Clear Segmentation & 0.15 & & & 4 & 0.60 & & \\
\hline 4 & $\begin{array}{l}\text { HR Development } \\
\text { Priorities }\end{array}$ & 0.10 & 4 & 0.40 & & & 4 & 0.40 \\
\hline 5 & $\begin{array}{l}\text { Using modern } \\
\text { technology }\end{array}$ & 0.20 & & & & & 3 & 0.60 \\
\hline 6 & $\begin{array}{l}\text { Put the client as the } \\
\text { main one }\end{array}$ & 0.15 & & & 4 & 0.60 & 2 & 0.30 \\
\hline & Weakness & & & & & & & \\
\hline 1 & $\begin{array}{c}\text { Do not have an adequate } \\
\text { HR consultant bureau }\end{array}$ & 0.05 & & & & & 4 & 0.20 \\
\hline 2 & $\begin{array}{c}\text { There are no ads specific } \\
\text { to the company }\end{array}$ & 0.05 & & & & & & \\
\hline 3 & $\begin{array}{l}\text { Not all big cities are } \\
\text { affordable }\end{array}$ & 0.10 & & & 4 & 0.40 & 2 & 0.20 \\
\hline
\end{tabular}

Table 4: Quantitative Strategic Planning Matrix (QSPM) Matrix

\begin{tabular}{|c|c|c|c|c|c|c|c|c|}
\hline & Opportunity & & & & & & & \\
\hline 1 & $\begin{array}{l}\text { The amount of national } \\
\text { infrastructure } \\
\text { development }\end{array}$ & 0.15 & 3 & 0.45 & 3 & 0.45 & & \\
\hline 2 & $\begin{array}{l}\text { Increased demand for } \\
\text { office space and high } \\
\text { occupancy in major } \\
\text { cities in Indonesia }\end{array}$ & 0.15 & 4 & 0.60 & 4 & 0.60 & & \\
\hline 3 & $\begin{array}{c}\text { Construction companies } \\
\text { are basic needs }\end{array}$ & 0.15 & 4 & 0.60 & 4 & 0.60 & 4 & 0.60 \\
\hline \multirow[t]{2}{*}{4} & Opening of MEA & 0.05 & 2 & 0.10 & & & & \\
\hline & \multicolumn{8}{|l|}{ Threat } \\
\hline 1 & $\begin{array}{c}\text { The emergence of new } \\
\text { construction companies } \\
\text { and old construction } \\
\text { companies }\end{array}$ & 0.20 & 4 & 0.80 & 4 & 0.80 & & \\
\hline 2 & $\begin{array}{l}\text { There is an increase in } \\
\text { material prices, fuel, } \\
\text { even the rupiah } \\
\text { exchange rate }\end{array}$ & 0.15 & & & 2 & 0.30 & & \\
\hline 3 & $\begin{array}{c}\text { There is a high } \\
\text { complexity in carrying } \\
\text { out work }\end{array}$ & 0.05 & 4 & 0.20 & & & 4 & 0.20 \\
\hline 4 & $\begin{array}{l}\text { The possibility of a land } \\
\text { sliding (landslide) } \\
\text { around the project }\end{array}$ & 0.05 & 4 & 0.20 & & & 4 & 0.20 \\
\hline 5 & $\begin{array}{c}\text { There is a price war } \\
\text { strategy }\end{array}$ & 0.05 & & & & & & \\
\hline & Total & & & 3.95 & & 4.35 & & 3.25 \\
\hline
\end{tabular}

Table 5

From the QSPM analysis table, it can be concluded that the business expansion strategy has the highest value of 4.35, this indicates that business expansion is the most suitable strategy to be implemented by PT. Total Bangun Persada Tbk. Business expansion can be done by opening a new branch of the company in the big cities, it can be achieved if PT. Total Bangun Persada Tbk builds cooperation with existing local construction companies.

The next strategy that must be carried out by PT. Total Bangun Persada Tbk based on the table is developing innovation, which in QSPM analysis has a value of 3.95. This strategy can be done by creating competition within the 
company for employees to motivate employees to create creative ideas that can meet consumer needs, both in terms of design and quality offered.

The third strategy that must be carried out by PT. Total Bangun Persada Tbk is by developing human resources, which based on the table above is at a value of 3.25. This strategy can be achieved by involving new employees in training on construction services, both design, quality, and even ways of managing project management.

\section{Conclusion}

From the analysis carried out through the SWOT matrix, several strategies were obtained that could be developed by PT. Total Bangun Persada Tbk, among others, continues to develop innovations, opening the opportunities for foreign workers (MEA), widen the range of service areas - diversification, making a consultant for promotion, establishing branch offices in major cities in Indonesia, strengthening corporate image through CSR activities, still prioritizing quality event though the price is attacked, building cooperation with local contractors in other major cities.

From each existing strategy, the three best strategies were chosen to be analyzed using the QSPM matrix which can then be developed and applied as a company strategy to increase the competitive advantage of the company. From the results of the QSPM matrix, it is known that business expansion is a strategy that must be immediately developed and applied by PT. Total Bangun Persada Tbk. This strategy can be developed by opening new branches in other big cities and building cooperation with local contractor, or by products diversification. For product diversification, total build PT. Total Bangun Persada Tbk can offer construction services that are different from high rise building construction, for example by building mosques, churches, schools, or even hospitals. When there are more service options, it is expected to meet existing market needs.

However, PT. Total Bangun Persada might face challenges in implementing these strategies. In its efforts to open new branch offices and establish cooperation with local contractors, PT. Total Bangun Persada Tbk may experience resistance in establishing cooperation because local construction companies feel threatened by the existence of PT. Total Bangun Persada Tbk in their city. For product diversification, challenges that might be faced by PT. Total Bangun Persada Tbk is a price war with other construction companies that have first focused on the type of bar services that will be offered.

Even though PT. Total Bangun Persada Tbk is the ten largest construction companies in Indonesia, PT. Total Bangun Persada Tbk must continue to strive to develop itself so that it can continue to survive and continue to have high competitiveness when compared to other construction companies that continue to grow and increase in Indonesia.

\section{References}

i. Annual Report. 2017. PT. Total Bangun Persada Tbk.

ii. Hany Setyorini, Mas'ud Effendi, Imam Santoso. 2016. Analisis Strategi Pemasaran Menggunakan Matriks SWOT dan QSPM (Studi Kasus: Restoran WS Soekarno Hatta Malang). Industria: Jurnal Teknologi dan Manajemen Agroindustri Vol 5(1): 46-53.

iii. Suci Purwandari. 2015. Analisis Quantitative Strategic Planning Matrix (Qspm) Sebagai Landasan Menentukan Strategi Pemasaran Pada Smk Citra Medika Sukoharjo. Jurnal Sainstech Politeknik Indonusa Surakarta 1(3):1-9.

iv. Zulkarnaen, H. O., dan Sutopo. (2013). Analisis Strategi Pemasaran pada Usaha Kecil Menengah (UKM) Makanan Ringan (Studi Penelitian UKM Snack Barokah di Solo). Diponegoro Journal of Management. 2(3): 1-13. 